\title{
Evaluation of Sesame (Sesamum indicum L.) Genotypes to the Shaded Uplands of Southern Region
}

\author{
A. Abhijatha ${ }^{1}$, K. Arya ${ }^{1}$, Kuduka Madhukar ${ }^{2}$ and Srinivas Gogineni ${ }^{1}$ \\ ${ }^{1}$ Department of Plant Breeding and Genetics, College of Agriculture, Vellayani, \\ Trivandrum-695522, Kerala, India \\ ${ }^{2}$ Department of Genetics and Plant Breeding, Institute of Agricultural Sciences, BHU, \\ Varanasi-221005, U.P., India \\ *Corresponding author
}

\section{A B S T R A C T}

The sesame germplasm consisting of thirty three accessions were assessed for the extent of variability, degree and direction of character association among yield and its contributing traits and the direct and indirect effects of various components on yield.

Keywords

Sesame, Shade tolerance, Variability, GCV, Correlation analysis.

Article Info

Accepted: 04 June 2017 Available Online: 10 July 2017 Analysis of variance showed significant differences among the genotypes for almost all the characters studied. High and moderate phenotypic and genotypic coefficients of variation (PCV and GCV) were noticed for most of the yield contributing characters. Highest and lowest PCV and GCV were recorded for number of capsules per unit length and 1000-seed weight respectively. High estimates of heritability coupled with high to moderate genetic advance as per cent over mean was recorded for all the yield associated traits except for days to maturity, oil content and 1000-seed weight. Yield had positive and significant association with the yield contributing characters such as plant height, number of primary branches, number of capsules per plant, length of capsule and number of seeds per capsule, signifying that selection based on these characters may improve yield. The highest genotypic and phenotypic correlation with yield was observed for number of capsules per plant. Path analysis revealed that number of capsules per plant had the highest positive direct effect on seed yield per plant followed by number of seeds per capsule. Number of primary branches per plant and days to maturity had the maximum positive indirect effect on seed yield per plant through number of capsules per plant.

\section{Introduction}

Sesame (Sesamum indicum L., $2 \mathrm{n}=2 \mathrm{x}=26$ ) commonly known as gingelly, til, and tila in Sanskrit, is a member of the order Tubiflorae and family Pedaliaceae. Sesame is highly valued for its cooking quality, medicinal value of its oil, high seed oil content (50$60 \%)$, protein $(18-25 \%)$, calcium, phosphorous, oxalic acid and excellent qualities of the seed oil and oil cake. Sesame crop has many agricultural advantages.
It is grown on residual soil moisture with low inputs, and is a good crop for rotations with an extensive tap root system (Ashri, 1998). India is considered to be the major centre of genetic diversity even though the crop originated in Africa (Maiti et al., 2012). In India, sesame is cultivated in an area of 1.94 $\mathrm{m}$ ha with $0.755 \mathrm{~m}$ ton production (Gayathri, 2011). However, the average productivity of sesame in India (453 $\left.\mathrm{kg} \mathrm{ha}^{-1}\right)$ is far below the 
average productivity in China (1127 kg ha $\left.{ }^{-1}\right)$ and Egypt $\left(1211 \mathrm{~kg} \mathrm{ha}^{-1}\right)$. In Kerala, sesame is mainly cultivated in summer rice fallows. During 1990-91, 5.59 lakh hectares were under paddy; however during 2009-10 it was only 2.34 lakhs ha. Thus within two decades, there was a decline of 3.25 lakh hectares (Kumari, 2011).

Shrinking lowlands, shortage of labour and unprecedented summer showers resulting in crop failure, are the major reasons for the dwindling sesame cultivation in the state. Upland sesame cultivation is gaining importance in this scenario. Coconut gardens are the potential areas where we can intervene for upland sesame cultivation in the state since there has been a 28 per cent increased area under coconut over a period of twenty years (Govt. of Kerala, 2006). This highlights the need to enhance the productivity of the crop by developing high yielding genotypes. A thorough screening of the available germplasm for genetic variability for yield and its component traits will help in identifying elite genotypes.

\section{Materials and Methods}

The experiment was conducted in the field of Instructional Farm, College of Agriculture, Vellayani, during rabi season, 2012-13 in a Randomized Block Design in a coconut garden. A spacing of $30 \mathrm{~cm} \times 15 \mathrm{~cm}$ between plants was adopted. The material for study comprised of thirty three genotypes of sesame collected from various research stations including the varieties from Kerala Agricultural University. Observations were recorded on five random competitive plants in each replication for following traits viz., days to 50 per cent flowering, plant height, days to maturity, number of capsules per unit length, number of primary branches per plant, number of capsules per plant, length of the capsule, number of seeds per capsule, seed yield per plant, 1000-seed weight, root length and oil content.

The biometric observations recorded were subjected to ANOVA (Panse and Sukhatme, 1985) for comparison among various treatments and to estimate variance components. The phenotypic and genotypic variances were calculated by utilizing the respective mean square values (Johnson et al., 1955).

The genotypic and phenotypic coefficients of variation were calculated by following Burton (1952). Categorization of the range of variation was effected as proposed by Sivasubramanian and Menon (1973).

Both heritability percentage $\left(h^{2}\right)$ in broad sense and genetic advance (GA) as percentage of mean was estimated and categorized for various characters as per the formulae suggested by Johnson et al., (1955).

\section{Results and Discussion}

The analysis of variance revealed highly significant differences among the thirty three genotypes for all the traits studied except for 1000 -seed weight, indicating the presence of substantial amount of variability and selection could be effective for improvement of those characters (Table 1).

Similar results have also been reported by Valarmathi et al., (2004) and Raghuwanshi (2005).

\section{Phenotypic and genotypic coefficients of variation}

High GCV was shown by characters number of capsules per unit length, number of primary branches, seed yield per plant, root length and number of capsules per plant, clearly indicating that selection will be 
rewarding (Fig. 1). These results are in agreement with those of Valarmathi et al., (2004). The estimates of PCV and GCV were high for the characters number of primary branches per plant, number of capsules per plant and seed yield per plant. Similar results were reported by Mandal et al., (2010) and Gayathri (2011). Low estimates of GCV for days to 50 per cent flowering, days to maturity, number of seeds per capsule, oil content and 1000-seed weight indicated limited scope for improvement of these characters through selection due to low magnitude of heritable variation.

Thangavel et al., (2000) published comparable results on estimates of GCV and PCV. The genotypes exhibited significant variation for oil content. The highest oil content noticed was 50.16 per cent and the lowest was 45.52 per cent with a mean of 48.59 per cent. Similar results were earlier reported by Shadakshri et al., (1995).

\section{Heritability and genetic advance}

High heritability combined with high genetic advance (as per cent of mean) was observed for number of capsules per unit length, seed yield per plant, number of primary branches, plant height, root length and number of capsules per plant indicating these characters were controlled by additive gene effects and phenotypic selection for these characters is likely to be effective (Fig. 2).

Table.1 Analysis of variance for various characters of sesame genotypes

\begin{tabular}{|l|c|c|c|}
\hline \multirow{2}{*}{ Characters } & \multicolumn{3}{|c|}{ Mean sum of squares } \\
\cline { 2 - 4 } & Replication & Genotypes & Error \\
\hline Days to 50\% flowering & 3.363 & $21.017^{* *}$ & 0.645 \\
\hline Plant height (cm) & 293.011 & $130.88^{* *}$ & 5.364 \\
\hline Days to maturity & 26.250 & $57.332^{* *}$ & 1.420 \\
\hline No. primary branches & 0.010 & $5.911^{* *}$ & 0.020 \\
\hline No. capsules/plant & 4.859 & $55.224^{* *}$ & 0.120 \\
\hline No. capsules/unit length & 0.007 & $0.041^{*}$ & 0.001 \\
\hline Length of capsule (cm) & 0.023 & $0.185^{*}$ & 0.003 \\
\hline No. seeds/capsule & 4.734 & $55.022^{* *}$ & 0.977 \\
\hline Root length (cm) & 1.149 & $13.704^{* *}$ & 0.027 \\
\hline Oil content (\%) & 0.016 & $4.299^{* *}$ & 0.001 \\
\hline 1000-seed weight (g) & 0.001 & 0.001 & 0.001 \\
\hline Seed yield/plant (g) & 0.207 & $1.449^{*}$ & 0.004 \\
\hline
\end{tabular}

${ }^{*}$ Significant at $5 \%$ level; ${ }^{* *}$ Significant at $1 \%$ level 
Int.J.Curr.Microbiol.App.Sci (2017) 6(7): 332-339

Table.2 Genotypic correlation among various characters of sesame

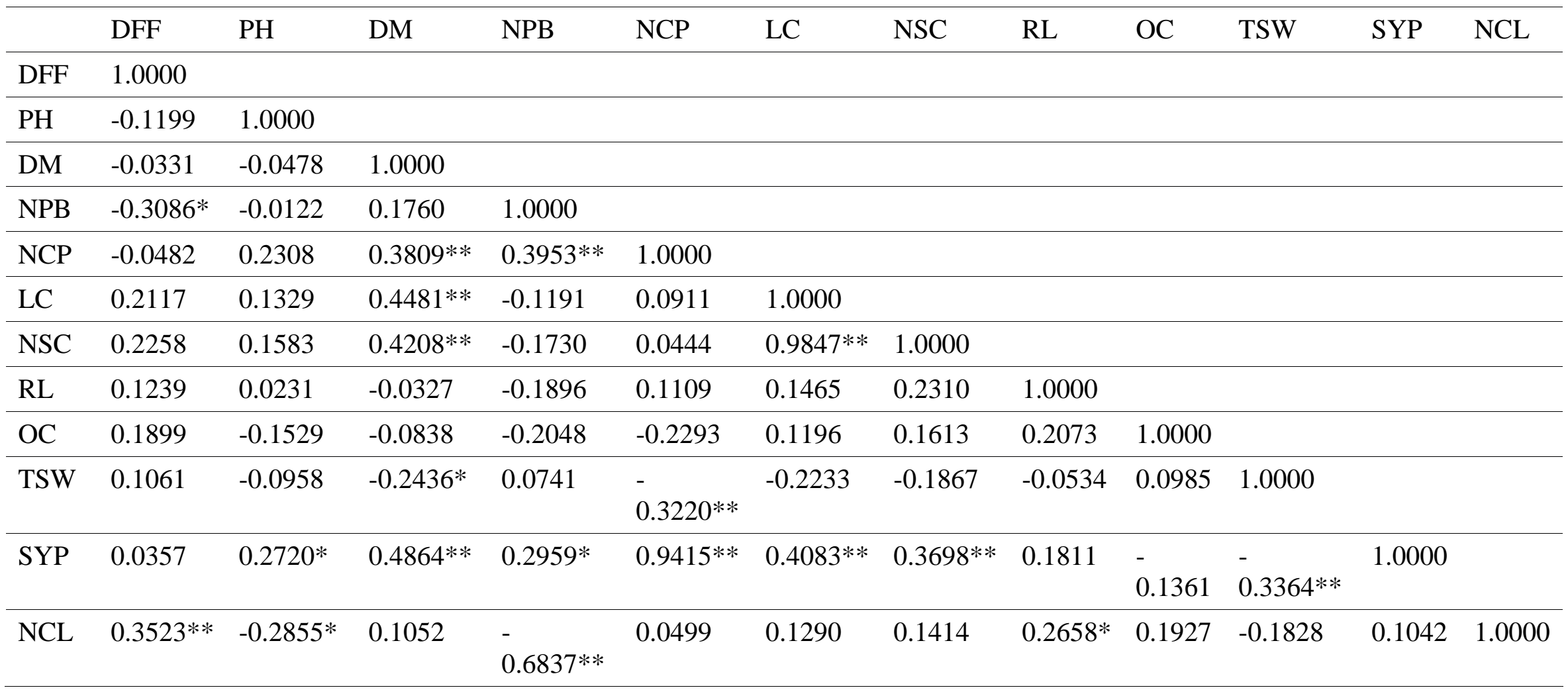

DFF- Days to first flowering

PH- Plant height (cm)

DM- Days to maturity

NPB- Number of primary branches/plant

NCP- Number of capsules/plant

LC- Length of capsule (cm)

*-Significant at $5 \%$ level

*-Significant at 5\% level
NSC- Number of seeds/capsule

RL- Root length $(\mathrm{cm})$

OC- Oil content (\%)

TSW- 1000 seed weight $(\mathrm{g})$

SYP- Seed yield/plant (g)

NCL- Number of capsules/unit length 


\section{Int.J.Curr.Microbiol.App.Sci (2017) 6(7): 332-339}

Fig.1 PCV (\%) and GCV (\%) for various characters of sesame genotypes

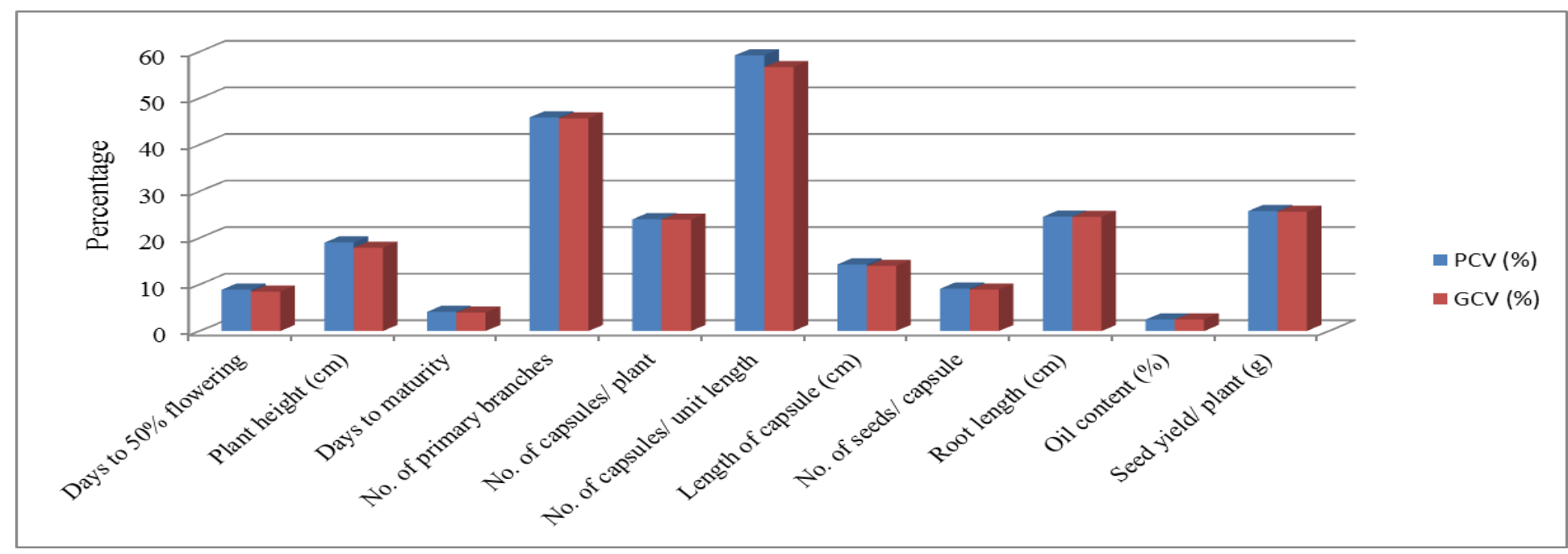

PCV: Phenotypic coefficient of variation

GCV: Genotypic coefficient of variation

Fig.2 Heritability (\%) and genetic advance (\%) for various characters of sesame genotypes

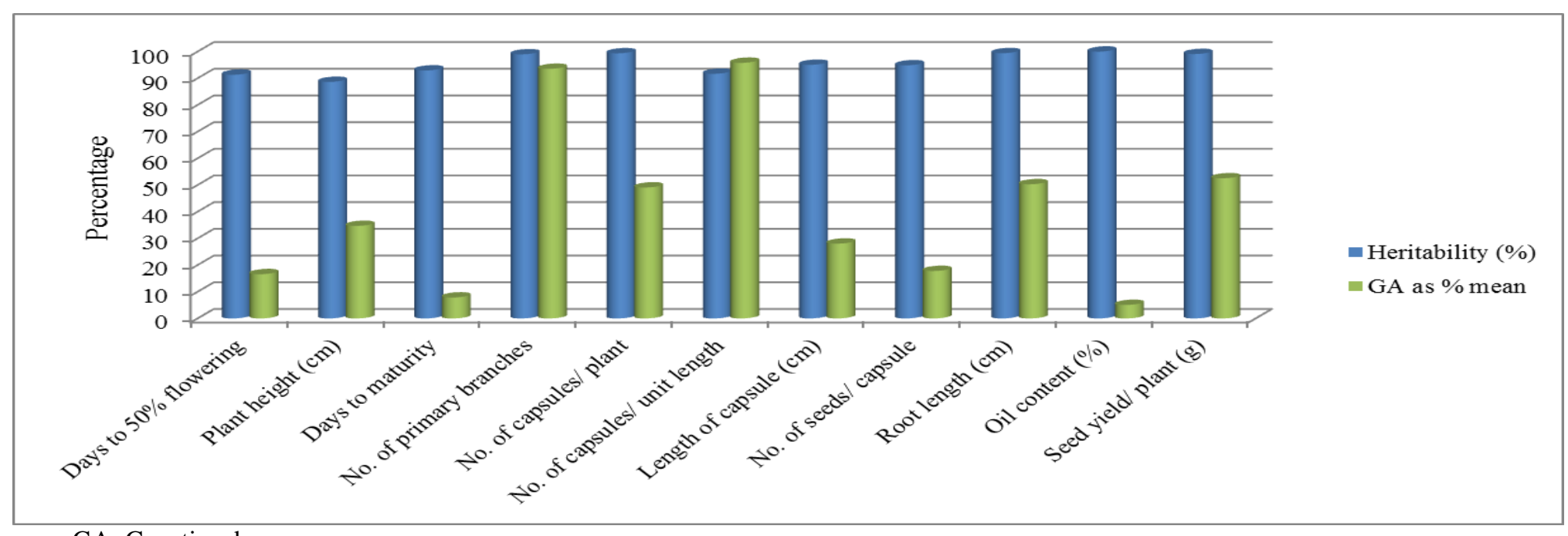

GA: Genetic advance 
Fig.3 Path diagram

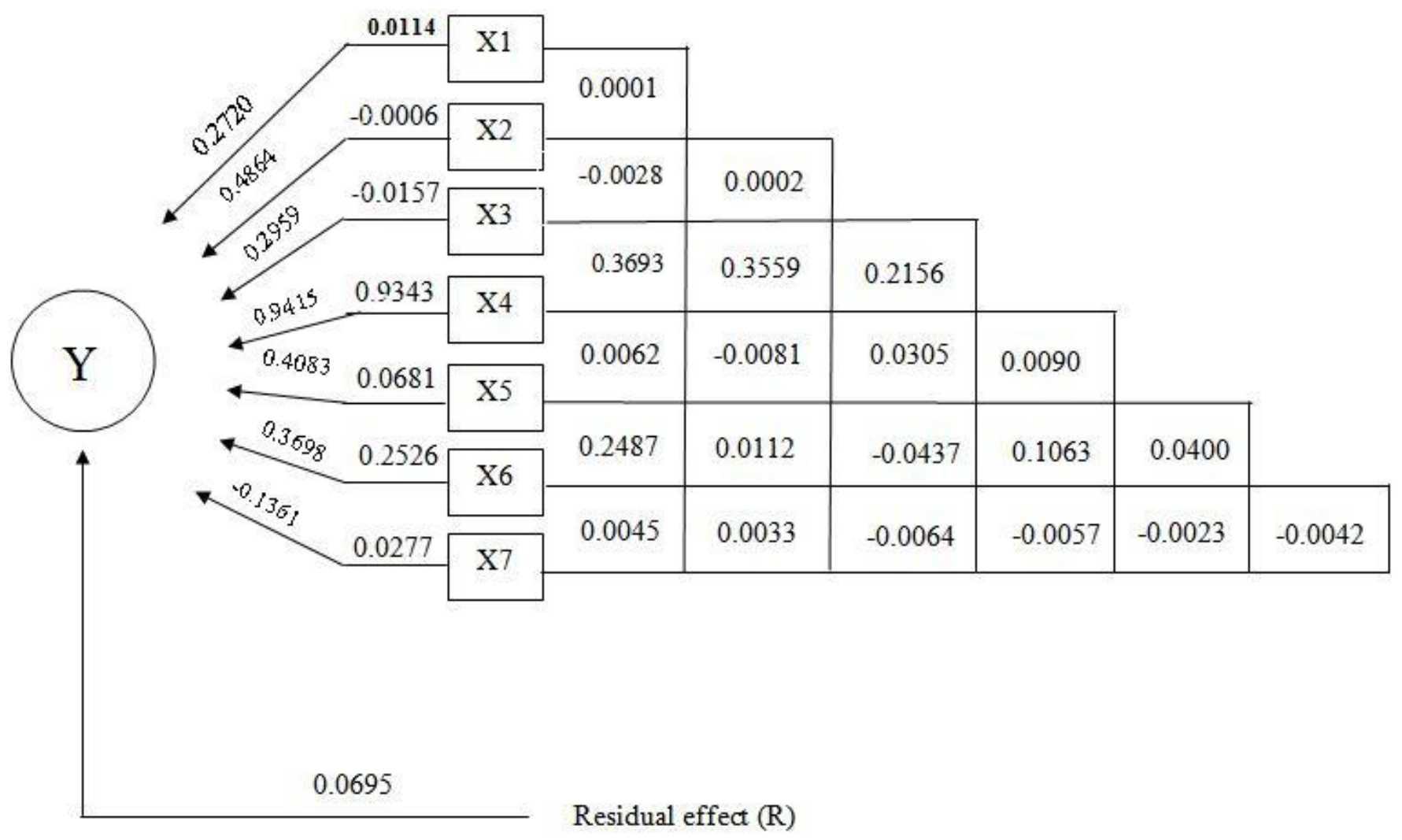

X1: Plant height $(\mathrm{cm})$

$\mathrm{X} 2$ : Days to maturity

X3: Number of primary branches/plant

$\mathrm{X} 4$ : Number of capsules/plant
X5: Length of capsule $(\mathrm{cm})$

X6: Number of seeds/capsule

X7: Oil content (\%) 
The path analysis revealed that seed yield per plant was positively and directly affected by the number of capsules per plant followed by number of seeds per capsule. All these had positive genotypic correlations with seed yield (Table 1 and Fig. 3). The greater influence of these traits reflects their importance as seed yield components. Similar results were reported by Mothilal (2005). Shajan (2002) and Kurdistani et al., (2011) reported that number of capsules per plant had the highest positive direct effect on seed yield which is in conformity with the present observation. Plant height, number of capsules per plant, length of capsule, number of seeds per capsule and oil content showed positive direct effect on yield similar to the earlier report by Vidhyavati et al., (2005) and Mohan (2011). The direct negative effect of days to maturity and number of primary branches per plant were in analogous to the reports of Siddiqui et al., (2005). The indirect effect of number of capsules per plant on seed yield through plant height, days to maturity, number of primary branches, length of capsule and number of seeds per capsule. Sumathi et al., (2007) and Georgiev et al., (2012) confirmed equivalent outcomes for plant height, days to maturity and number of primary branches and Gnanasekaran et al., (2008) for number of primary branches. Path analysis revealed that number of capsules per plant recorded the highest positive direct effect with seed yield per plant followed by number of seeds per capsule and plant height. However, number of primary branches per plant and days to maturity expressed negative direct effect. Similar reports have been given by Manjunatha et al., (2008), Parameswarappa et al., (2009) and Gayathri (2011).

\section{Acknowledgments}

I am grateful to Kerala Agricultural University (KAU) for granting me KAU-
Junior Research Fellowship (JRF) for my M.Sc. (Ag.) programme. We are thankful to the Department of Plant Breeding and Genetics, KAU, Vellayani for extending help during the course of work.

\section{References}

Ashri, A. 1998. Sesame breeding. Pl. Breed. Rev. 16: $179-228$.

Banerjee, P.P. and Kole, P.C. 2006. Genetic variability and yield analysis in sesame (Sesamum indicum L.). Crop Res. Hisar 32(3): 430-433.

Burton, G.W. 1952. Quantitative inheritance in grasses. Proc. $6^{\text {th }}$ Int. Grassland Congress 1: $277-283$

Ganesan, K.N. 2005. Variability studies in determinate type sesame (Sesamum indicum L.) germplasm lines for yield and its component traits. J. Oilseeds Res. 22(1): 176-177.

Gayathri, G. 2011. Heterosis breeding in sesame (Sesamum indicum L.). $\mathrm{PhD}$ (Ag) thesis, Kerala Agricultural University, Thrissur, $180 \mathrm{p}$.

Georgiev, S., Stamatov, S. and Deshev, M. 2012. Examination of the selection criteria in sesame (Sesamum indicum L.) using phenotypic correlations and path analysis. Agrarni Nauki. 4(10): 71-75.

Gnanasekaran, M., Jebaraj, S. and Muthuramu, S. 2008. Correlation and path co-efficient analysis in sesame (Sesamum indicum L.). Plant Archives 8(1): 167-169.

Government of Kerala, 2006. Area, production and productivity trends of important crops in Kerala from 1985-86 to 2004-05. Department of Economics and Statistics, Thiruvananthapuram. pp. 4.

Johnson, H.W., Robinson, H.F. and Comstock, R.E. 1955. Estimates of genetic and environmental variability in soyabeans. Agron. J. 47: 314-318.

Kumari, S.L. 2011. http://www.rkmp.co.in

Kurdistani, R., Tohidinejad, E., MohammadiNejad, G. and Zareie, S. 2011. Yield potential evaluation and path analysis of different sesame genotypes under various levels of iron. African. J. Pl. Sci. 5:862- 
866.

Maiti, R., Satya, P., Rajkumar, D. and Ramaswamy, A. 2012. Crop Plant Anatomy pp.141-146.

Mandal, R.K., Suman, S.J., Ojha, R.K. and Ram, S. 2010. Genetic variability in the germplasm of sesame (Sesamum indicum L.). Environ. Ecol. 28(4): 2556-2561.

Manjunatha, M.H., Suvarna, Manjunath, A. and Shankar, M.A. 2008. Estimates of genetic variability, association and path coefficient analysis in sesame (Sesamum indicum L.) over locations during late kharif. Res. Crops 9(1): 159-164.

Mohan, Y.C. 2011. Genetic variability and character association studies in sesame (Sesamum indicum L.). Crop Res. Hisar. 42(3): 259-262.

Mothilal, A. 2005. Correlation and path analysis in sesame (Sesamum indicum L.). Environ. Ecol. 233(3): 478-480.

Panse, V.G. and Sukhatme, P.V. 1985. Statistical methods for agricultural workers. ICAR, New Delhi. 278p.

Parameshwarappa, S.G., Palakshappa, M.G., Salimath, P.M. and Parameshwarappa, K.G. 2009. Studies on genetic variability and character association in germplasm collection of sesame (Sesamum indicum L.). Karnataka J. Agric. Sci. 22(2): 252-254.

Ramireddy, Kumar, A. and Sundaram, T. 2002. Inter-relationships among yield and yield components in sesame (Sesamum indicum L.) J. Res. 30 (2): 42-44.

Raghuwanshi, K.M.S. 2005. Study of genetic variability in sesame (Sesamum indicum L.). J. Maharashtra Agric. Univ. 30(3): 264-265.

Salah, B.M.A. and Abubakri, F.A. 2013. Variability of yield and some morphological traits in some sesame (Sesamum indicum L.) genotypes under rain-fed conditions. Int. J. Agric. Sci. Res.
2(2): 054-059.

Sankar, P.D. and Kumar, C.R.A. 2003. Character association and path coefficient analysis in sesame (Sesamum indicum L.). Agric. Sci. Digest 23(1): 17-19.

Shajan, V.R. 2002. Genetic basis of seed yield and seed quality in sesame, (Sesamum indicum L.). $\mathrm{PhD}(\mathrm{Ag})$ thesis, Kerala Agricultural University, Thrissur, 173p.

Siddiqui, M.A., Baig, K.S. and Patil, P.V. 2005. Correlation and path analysis studies for yield and yield contributing characters in sesamum (Sesamum indicum L.). J. Res. 33(1): 31-35.

Sivasubraramanian, S. and Menon, M. 1973. Heterosis and inbreeding depression in rice. Madras Agric. J. 60: 1139.

Sumathi, P., Balu, P.A. and Muralidharan, V. 2009. Association analysis of yield and yield contributing traits in sesame (Sesamum indicum L.) Adv. Pl. Sci. 22(1): 251-252.

Sumathi, P., Muralidharan, V. and Manivannan, N. 2007. Trait association and path coefficient analysis for yield and yield attributing traits in sesame (Sesamum indicum L). Madras Agric. J. 94(12): 174178.

Thangavel, P., Saravanan, K., Kumar, S.P., Anbuslvan, Y. and Ganesan, J. 2000. Variability, heritability and genetic advance in sesame (Sesamum indicum L.) Sesame and Safflower Newsl. 15: 19-22.

Valarmathi, G., Kumar, M. and Saravana, N.A. 2004. Genetic variability and correlation studies for seed related traits in Sesame (Sesamum indicum L.). Sesame and Safflower Newsl. 19.

Vidhyavathi, R., Manivannan, N. and Muralidharan, V. 2005. Association studies in sesame (Sesamum indicum L.). Agric. Sci. Digest 25(2): 130-132.

\section{How to cite this article:}

Abhijatha, A., Kuduka Madhukar and Arya, K. 2017. Evaluation of Sesame (Sesamum indicum L.) Genotypes to the Shaded Uplands of Southern Region. Int.J.Curr.Microbiol.App.Sci. 6(7): 332-339. doi: https://doi.org/10.20546/ijcmas.2017.607.039 